\title{
ANTIMICROBIAL SUSCEPTIBILITY OF LACTIC ACID BACTERIA ISOLATED FROM SOMBOR CHEESE
}

BULAJIĆ SNEŽANA and MIJAČEVIĆ ZORA

University of Belgrade, Faculty of Veterinary Medicine, Serbia

(Received 15th June 2010)

Extensive literature data pointed out that some lactic acid bacteria (LABs), the predominant microbiota in fermented dairy products, may serve as reservoirs of antibiotic resistance genes potentially transferable to human pathogens. Hence, there is a growing interest in the possible role of $\angle A B$ as vectors of antibiotic resistance determinants. This paper reports the susceptibility patterns of a number of LAB species (belonging to the genera Lactococcus, Lactobacillus, and Enterococcus) isolated from different batches of autochthonous Sombor cheese, traditionally made without the addition of starter cultures, and currently proposed as a candidate for PDO/PGI designation. The experimental work was performed to select strains that do not contain antibiotic resistance genes among those with desirable technological characteristics such as rapid acidification, proteolysis, ability to metabolise citrate and form aromogenic compounds. In addition, the results of these screening procedures could also indicate the types and degrees of antimicrobial resistance already present among the $L A B$ community of Sombor cheese, which according to their geographically restricted areas of production, specific manufacturing process and characteristic aroma and appearance, represent a distinct ecological niche. cheese

Key words: lactic acid bacteria, antibiotic resistance, Sombor

\section{INTRODUCTION}

Antimicrobial agents are commonly used in animal husbandry to cure or prevent the onset of bacterial infections. However, their use at subtherapeutic doses as growth promoters has led, over decades of use, to selection of antibiotic resistant bacteria within the intestinal microflora of treated livestock (Teuber, 2001; Wegener, 2003) with intrinsic potential transmission to humans through the food chain. The main threat associated with antibiotic resistance in commensal bacteria is the risk of horizontal transfer of its genetic determinant to pathogenic bacteria, thus impairing successful antibiotic treatment of common microbial infections. 
Extensive literature data pointed out that some lactic acid bacteria (LABs), the predominant microbiota in fermented dairy products, may serve as reservoirs of antibiotic resistance genes potentially transferable to human pathogens (Mathur and Singh, 2005). Hence, there is a growing interest in the possible role of LAB as vectors of antibiotic resistance determinants (Teuber et al., 1999). To address this aspect, the safety of this microorganism should be verified with respect to its ability to acquire and disseminate resistance determinants (Kastner et al., 2006).

Recently, the European Food Safety Authority (EFSA) has taken responsibility to launch the European initiative toward a "qualified presumption of safety" (QPS) concept which, similar to the GRAS system in the United States is aimed to allow strains with an established history and safety status to enter the market without extensive testing requirements (European Food Safety Authority, 2004). The presence of transmissible antibiotic resistance markers in the evaluation of strains is thus an important safety criterion.

However, there is still a lack of agreement on the resistance-susceptibility breakpoints for most antimicrobials in LAB (Charteris et al., 2001; Katla et al., 2001; Danielsen and Wind, 2003). Generally, the choice of medium has been shown to have a profound impact on the MICs of LAB. Furthermore, MIC breakpoints values have been shown to be species specific and thus vary between species of the same genera (Danielsen and Wind, 2003). Additionally, distinguishing between intrinsic, nonspecific, and acquired resistance is difficult and requires that the antimicrobial-resistance patterns of many $L A B$ species from different sources may be compared (Teuber et al., 1999). Intrinsic or "natural" resistance is inherent to a bacterial species and involves the absence of the target, low cell permeability, antibiotic inactivation and the presence of efflux mechanisms. The acquisition of antibiotic resistance occurs via the mutation of pre-existing genes or by horizontal transmission. With some exception, intrinsic resistance and resistance by mutation are unlikely to be disseminated; horizontally transferred genes, particularly those carried on mobile genetic elements, are those most likely to be transmitted (Normark and Normark, 2002). This is a very important task since genes conferring resistance to several antimicrobials (i.e., chloramphenicol, erythromycin, streptomycin, tetracycline, and vancomycin) located on transferable genetic elements (plasmids or transposons) have already been characterized in lactococci (Perreten et. al., 1997), lactobacilli (Axelsson et al., 1988; Danielsen, 2002) and enterococci (Eaton and Gasson, 2001; Huys et al., 2004) from food.

Lactococcus lactis strains were sensitive to amikacin, ampicillin, $1^{\text {st }}$ generation cephalosporins, chloramphenicol, erythromycin, gentamicin, imipenem, oxacillin, penicillin, pipericillin, sulphonamides, tetracycline, thrimetoprim/sulfomethoxazole, and vancomycin (de Fabrizio et al., 1994). Orberg and Sandine (1985) demonstrated that investigated strains of Lc. lactis subsp. cremoris and subsp. lactis were all resistant to trimethoprim and almost all to sulphathiazole. Resistance to gentamicin, kanamycin, lincomycin, neomycin, rifampin and streptomycin varied.

Generally, lactobacilli have a high natural resistance to bacitracin, cefoxitin, ciprofloxacin, fusidic acid, kanamycin, gentamycin, metronidazole, nitrofurantoin, norfloxacin, streptomycin, sulphadiazine, teicoplanin, trimethoprim/ sulphamethoxazole, and vancomycin (Danielsen and Wind, 2003). Literature data 
showed the existence of intergenus and interspecies differences and the speciesdependency of Lactobacillus spp. resistance to various antimicrobial agents. Strains of lactobacilli (Lactobacillus plantarum, L. acidophilus, L. brevis, L. casei) resistant to penicillin G, cloxacillin, streptomycin, gentamycin, tetracyclines, erythromycin and chloramphenicol were isolated from "home-made" Spanish cheeses (Serena, Gamonedo, Cabrales) (Herrero et al., 1996).

The strains of enterococci are naturally tolerant to $\beta$-lactams, cephalosporins, lincosamides and polymyxins. A specific cause for concern and a factor contributing to the pathogenesis of enterococci is the resistance they acquire to aminoglycosides, tetracyclines, macrolides, chloramphenicol, penicillin, and ampicillin (Gray et al., 1991), and their capacity to exchange genetic information by conjugation.

The traditional cheese-making technique of Sombor cheese has almost remained unchanged over the years in line with local practice and through the long period represented a well-protected family secret (Mijačević and Bulajić, 2008). Autochthonous Sombor cheese is fermented by microflora naturally occurring in raw milk used for cheese manufacturing. Its bacterial composition reflects therefore the most represented species within geographically restricted environments. Sombor cheese is an important source of very interesting strains of lactic acid bacteria, mainly lactobacilli, lactococci and enterococci with high potential of acidification, proteolytic and lipolytic activities, and production of aromogenic substances. As fermented foods may be important vehicles of enormous amount of living bacteria which may carry determinants of antibiotic resistance, it is important to screen the isolates of high technological potential to antibiotic resistance patterns.

This paper reports the susceptibility patterns of a number of LAB species (belonging to the genera Lactococcus, Lactobacillus, and Enterococcus) isolated from different batches of autochthonous Sombor cheese, traditionally made without the addition of starter cultures, and currently proposed as a candidate for PDO/PGI designation. This work was performed to select strains that do not contain antibiotic resistance genes among those with desirable technological characteristics such as rapid acidification, proteolysis, ability to metabolise citrate and form aromogenic compounds. In addition, the results of these screening procedures could also indicate the types and degrees of antimicrobial resistance already present among the LAB community of Sombor cheese, which according to their geographically restricted areas of production, specific manufacturing process and characteristic aroma and appearance, represent a distinct ecological niche.

\section{MATERIAL AND METHODS}

Bacterial strains, media and identification

The studied LAB strains were isolated from manufacturing and ripening of traditional Sombor cheese (traditionally made cheese without starters at different farmhouses). The isolates belonged to the dominant bacterial group (lactococci, lactobacilli and enterococci) and were isolated on agar plates of either M17 agar 
(lactococci), KAA agar (enterococci) or MRS agar (lactobacilli). They were first characterized by conventional fenotypic criteria and then by API 20 Strep System and $50 \mathrm{CH}$ according to producer's instruction.

\section{Antimicrobial susceptibility testing}

Antibiotic susceptibility testing was accomplished with the commercial test BBL Sensi-Disc Antimicrobial Susceptibility Test Discs, performing the standard disc diffusion method (National Committee for Clinical Laboratory Standards, 1993). The isolated strains of LAB were tested for resistance to 11 antibiotics: erythromycin $(15 \mu \mathrm{g})$, gentamicin $(120 \mu \mathrm{g})$, tetracycline $(30 \mu \mathrm{g})$, penicillin (10 IU), lincomycin $(2 \mu \mathrm{g})$, fusidic acid $(10 \mu \mathrm{g})$, neomycin $(30 \mu \mathrm{g})$, vancomycin $(3 \mu \mathrm{g})$, cefotaxime $(30 \mu \mathrm{g})$, ofloxacin $(5 \mu \mathrm{g})$, metronidazole $(80 \mu \mathrm{g})$. The level of antibiotic susceptibility for each isolate was reported as resistant, intermediate or sensitive according to the recomendations of the National Committee for Clinical Laboratory Standards (NCCLS, 2002).

The $E$ test strips (AB Biodisk, Sweden) was used to evaluate the MICs for each tested antibiotic. MRS/M17 agar plates were inoculated with the bacterial suspension with the turbidity equivalent to McFarland standard 1. After drying the surfaces of the plates, the E test strips of the tested antimicrobial agents (erythromycin, tetracycline and penicillin; 0,016 to $256 \mu \mathrm{g} / \mathrm{mL}$ ) were applied. The plates were properly incubated. MICs were read directly from the test strip according to the instructions of the manufacturer.

\section{RESULTS AND DISCUSSION}

In our study, representative strains of LAB were tested with 11 different antibiotics using the disc test method. The results obtained for antibiotic resistance of 116 LAB strains isolated from Sombor cheese and tested using the disc diffusion method are shown in Table 1.

According to the zone diameter interpretive standards (NCCLS, 2002) tested strains of LAB demonstrated different profiles of phenotypic antibiotic resistance and multiple resistance to tested antibiotics was observed. This is in accordance with various scientific reports indicating that $L A B$ are normally resistant to the principal types of antibiotics, such as â-lactam, cephalosporins, aminoglycosides, nitrofurantoin and fluoroquinolines (Halami et al., 2000). As expected, all analyzed strains were resistant to metronidazole, since LAB have no hydrogenase activity (Church et al., 1996).

When resistance to penicillin ( $\beta$-lactams) was tested, strains of Lactococcus spp. showed more susceptibility, while the highest prevalence of penicillin resistance was shown among the isolates of Lactobacillus spp. According to literature data, $\beta$-lactamases (a family of resistance enzymes) are involved in resistance to $\beta$-lactam antibiotics (Bush et al., 1995).

With regard to antimicrobials in Group II (non- $\beta$-lactam), 35 strains were resistant to vancomycin, and among these, only 1 strain of enterococci showed vancomycin resistance. According to Giraffa (2002), enterococci from European cheeses, mainly belonging to $E$. faecalis and $E$. faecium, are susceptible to 
different antibiotics in different proportions, as also was demonstrated by other authors (Teuber et al., 1999; Franz et al., 2001). From the study of European cheeses Teuber et al. (1999) ascertained that the incidence for vancomycin resistance among enterococcal isolates was as low as $4 \%$. When Franz et al. (2001) tested $47 \mathrm{E}$. faecalis strains, isolated mostly from cheese, they were all susceptible to vancomycin. In contrast, Citak and coworkers (2004) have shown resistance to vancomycin among the population of enterococci isolated from Turkish white cheeses and was found in $96.8 \%$ of $E$. faecalis isolates, and $76 \%$ of E. faecium. The susceptibility to vancomycin is of great importance as this glycopeptide antibiotic is one of the last therapeutic options in clinical therapy.

Table 1. Resistance to antibiotics of the representative strains of lactic acid bacteria isolated from Sombor cheese

\begin{tabular}{|c|c|c|c|c|}
\hline \multirow[b]{2}{*}{ Number of strains tested } & $\begin{array}{c}\text { Lactococcus } \\
\text { spp. }\end{array}$ & $\begin{array}{c}\text { Lactobacillus } \\
\text { spp. }\end{array}$ & $\begin{array}{c}\text { Enterococcus } \\
\text { spp. }\end{array}$ & Total \\
\hline & 82 & 19 & 15 & $\begin{array}{c}116 \\
\text { Resistant } \\
\text { strains } \\
\end{array}$ \\
\hline \multicolumn{5}{|l|}{$\begin{array}{l}\text { Rresistance to antimicrobials } \\
\text { of Group I }\end{array}$} \\
\hline Penicillin (10 IU) & 21 & 12 & 5 & 38 \\
\hline \multicolumn{5}{|l|}{$\begin{array}{l}\text { Resistance to antimicrobials } \\
\text { of Group II }\end{array}$} \\
\hline Vancomycin $(30 \mu \mathrm{g})$ & 22 & 12 & 1 & 35 \\
\hline \multicolumn{5}{|l|}{$\begin{array}{l}\text { Resistance to antimicrobials } \\
\text { of Group III }\end{array}$} \\
\hline Gentamicin $(120 \mu \mathrm{g})$ & 17 & 11 & 4 & 32 \\
\hline Tetracycline $(30 \mu \mathrm{g})$ & 64 & 12 & 9 & 75 \\
\hline Erythromycin $(15 \mu \mathrm{g})$ & 25 & 10 & 6 & 41 \\
\hline \multicolumn{5}{|l|}{ Neomycin $(30 \mu \mathrm{g})^{*}$} \\
\hline Lincomycin $(2 \mu \mathrm{g})$ & 76 & 17 & 12 & 105 \\
\hline \multicolumn{5}{|l|}{$\begin{array}{l}\text { Resistance to antimicrobials } \\
\text { of Group IV }\end{array}$} \\
\hline Metronidazole $(80 \mu \mathrm{g})$ & 82 & 19 & 15 & 116 \\
\hline
\end{tabular}

* no zone interpretation data available for neomycin

The highest prevalence of resistance to antimicrobials of Group III was shown in relation to lincomycin and tetracycline, with a similar grade of resistance to the rest of the antibiotics in Group III. Indeed, resistance to tetracycline has been widely reported in LAB species (Danielsen and Wind, 2003; Delgado et al., 2005; Florez et al., 2005; Temmerman et al., 2003). Some lactobacilli have a high natural resistance to gentamicin (Danielsen and Wind, 2003), while resistance to 
gentamicin, lincomycin and neomycin among the lactococcal strains varied (Orberg and Sandine, 1985).

Antibiotic resistance can be "intrinsic" or "acquired". Intrinsic or natural resistance is inherent to a bacterial species and involves chromosomally coded different resistance mechanisms such as absence of the target, low cell permeability, antibiotic inactivation and the activity of an efflux system. The acquisition of antibiotic resistance is generated via the mutation of a pre-existing gene or by horizontal transmission. As intrinsic resistance and resistance by mutation are unlikely to be disseminated, so the risk is characterized by horizontally transferred genes, especially those carried on mobile genetic elements (Normark and Normark, 2002). Therefore, distinction between natural and acquired antibiotic resistance among the population of $L A B$ is of a great importance, since only the latter has the potential of being transferred (Anadon et al., 2005). Analysis of MICs and their distributions in defined species/antibiotic combinations helps to differentiate between these 2 resistance mechanism.

In this study the MICs of 3 antibiotics (penicillin, tetracycline and erythromycin) for LAB strains were analyzed (Table 2).

The highest MICs for penicillin were shown by the strain of Lactobacillus paracasei subsp. paracasei, Lactococcus lactis subsp. lactis and Enterococcus casseliflavus $(32 \mu \mathrm{g} / \mathrm{ml})$. Cell-wall impermeability seems to be the main mechanism of resistance to inhibitors of cell-wall synthesis (penicillins and cephalosporins) (Condon, 1983), but nonspecific mechanisms, such as multidrug transporters (Putman et al., 2001), and defective cell wall autolytic systems (Kim et al., 1982), may also account for the differences between strains.

The MICs of antibiotics affecting the synthesis of proteins (tetracycline and erythromycin) showed the greatest variation between species. Although most tested strains of $L A B$ were susceptible, a few moderate to strongly resistant strains were seen (Table 2). Resistance to high levels of erythromycin ( $M I C=\geq 256 \mu \mathrm{g} / \mathrm{mL}$ ) were confirmed for 1 strain of Lactococcus lactis subsp. lactis and Lactobacillus paracasei subsp. paracasei. When a bacterial strain demonstrates higher resistance to a specific antibiotic than the other strains of the same taxonomical unit, the presence of acquired resistance is indicated and there is a need for further analysis to confirm the genetic basis of resistance (EFSA, 2008).

According to Murray and coworkers (2003) the MIC distribution of a given antibiotic for a single bacterial species in the absence of resistance mechanisms should approach statistical normality while bimodal distribution of MICs values suggest acquired resistance. For the purpose of identifying bacterial strains with acquired and potentially transferable antibiotic resistance, a microbiological breakpoint has recently been defined. Microbiological breakpoints are set by studying the MICs distribution in the bacterial population and the part of population that clearly deviates from a susceptible majority is considered resistant (Olsson-Liljequist et al., 1997). In this paper we have defined microbiological breakpoints as the MICs were immediately above the apparent normal range for a given antibiotic and given species (Table 3). It should be noted that these guidelines are suggestions that might change as more strains are tested. 
Acta Veterinaria (Beograd), Vol. 61, No. 2-3, 247-258, 2011.

Bulajić Snežana and Mijačević Zora: Antimicrobial susceptibility

of lactic acid bacteria isolated from Sombor cheese

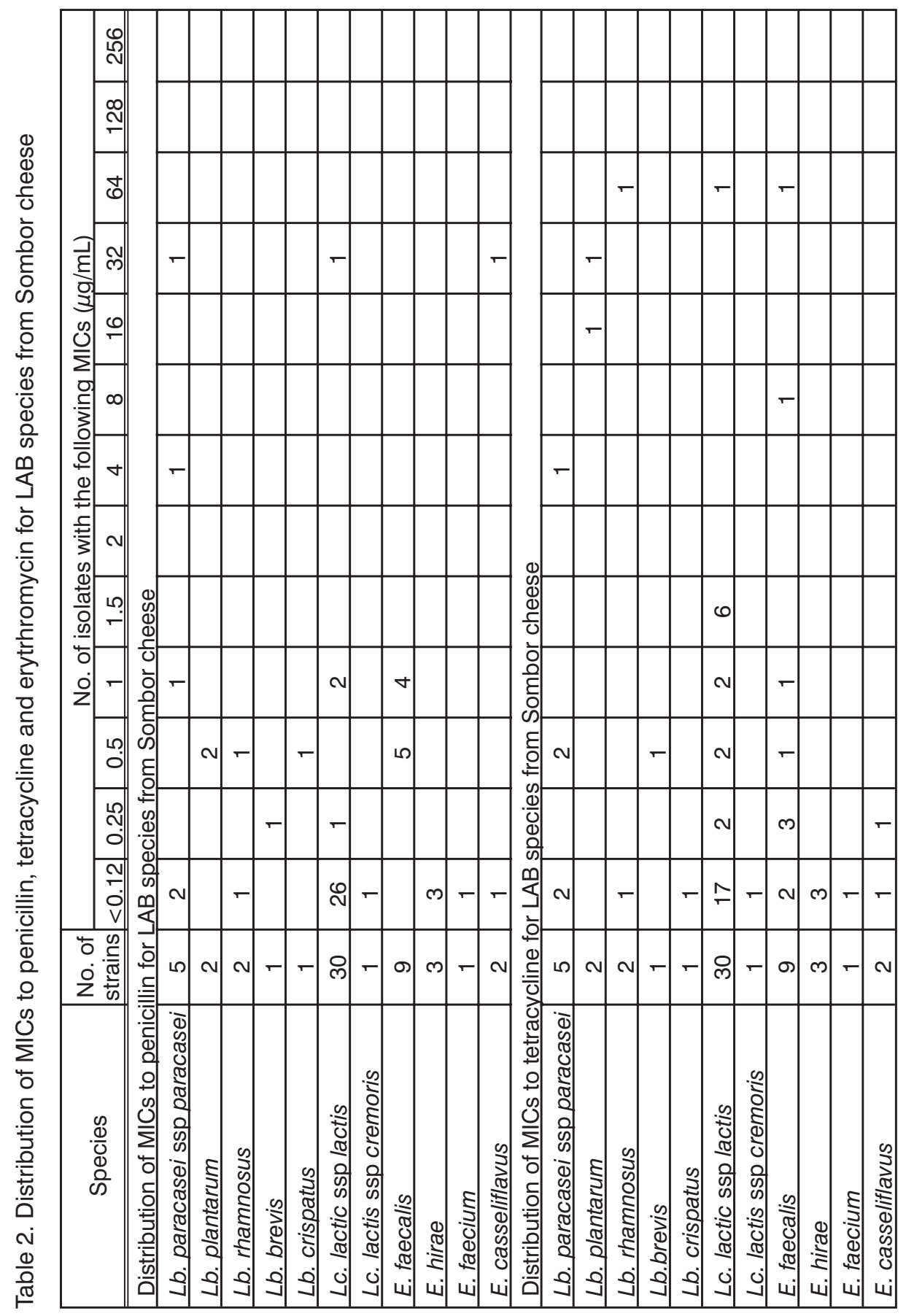




$$
[
$$


Strains with MICs equal to or higher than the breakpoints are considered resistant. Reference values for microbiological breakpoints proposed by Panel on Additives and Products or Substances used in Animal Feed (FEEDAP) (EFSA, 2008) were included for comparison.

Table 3. Microbiological breakpoints for LAB species from Sombor cheese

\begin{tabular}{|c|c|c|c|}
\hline \multirow{2}{*}{ Antibiotic } & \multirow{2}{*}{ Species } & \multicolumn{2}{|c|}{$\begin{array}{c}\text { Proposed breakpoints MIC } \\
(\mu \mathrm{g} / \mathrm{mL})\end{array}$} \\
\hline & & This work & $\begin{array}{c}\text { FEEDAP } \\
\text { (EFSA, 2008) }\end{array}$ \\
\hline \multirow{10}{*}{ Penicillin } & \multicolumn{3}{|c|}{ Lactobacillus facultative heterofermentative } \\
\hline & Lb. paracasei ssp paracasei & 2 & 2 \\
\hline & Lb. plantarum & 2 & 2 \\
\hline & Lb. rhamnosus & 2 & 4 \\
\hline & \multicolumn{3}{|c|}{ Lactobacillus obligate heterofermentative } \\
\hline & Lb.brevis & 2 & 2 \\
\hline & \multicolumn{3}{|c|}{ Lactobacillus obligate homofermentative } \\
\hline & Lb. crispatus & 1 & 1 \\
\hline & Lc. lactis & 2 & 2 \\
\hline & Enterococcus spp. & 2 & 4 \\
\hline \multirow{10}{*}{ Tetracycline } & \multicolumn{3}{|c|}{ Lactobacillus facultative heterofermentative } \\
\hline & Lb. paracasei ssp paracasei & 4 & 4 \\
\hline & Lb. plantarum & 32 & 32 \\
\hline & Lb. rhamnosus & 2 & 8 \\
\hline & \multicolumn{3}{|c|}{ Lactobacillus obligate heterofermentative } \\
\hline & Lb.brevis & * & 8 \\
\hline & \multicolumn{3}{|c|}{ Lactobacillus obligate homofermentative } \\
\hline & Lb. crispatus & * & 4 \\
\hline & Lc. lactis & 2 & 4 \\
\hline & Enterococcus spp. & 2 & 2 \\
\hline \multirow{10}{*}{ Erythromycin } & \multicolumn{3}{|c|}{ Lactobacillus facultative heterofermentative } \\
\hline & Lb. paracasei ssp paracasei & 1 & 1 \\
\hline & Lb. plantarum & 1 & 1 \\
\hline & Lb. rhamnosus & 1 & 1 \\
\hline & \multicolumn{3}{|c|}{ Lactobacillus obligate heterofermentative } \\
\hline & Lb. brevis & 1 & 1 \\
\hline & \multicolumn{3}{|c|}{ Lactobacillus obligate homofermentative } \\
\hline & Lb. crispatus & 1 & 1 \\
\hline & Lc. lactis & 2 & 2 \\
\hline & Enterococcus spp. & 4 & 4 \\
\hline
\end{tabular}

* MIC not estasblished because of small number of tested strains 
It should be noted that these guidelines are suggestions that might change as more strains are tested. Reference values for MICs of majority analyzed LAB species, established in this study, were in accordance to those set up by FEEDAP (EFSA, 2008).

\section{CONCLUSION}

In conclusion, it is a well established fact that lactic acid bacteria, the predominant microflora in fermented dairy products, may act as reservoirs of antibiotic resistant genes potentially transferable to human pathogens (Mathur and Singh, 2005). It is therefore of crucial importance to identify the presence of antibiotic resistant strains in fermented food, furthermore, qualify the MICs of resistant strains in order to evaluate the genetic base of resistance and possibility of transfer. Generally, only the minority of LAB strains isolated from Sombor cheese showed antibiotic resistance to tested antibiotics. However, this small fraction justifies performing the antibiotic susceptibility testing to avoid the microbiological hazards link with horizontal transfer of antibiotic resistance genes.

Address for correspondence:

Dr Snežana Bulajić

Department of Food Hygiene and Technology

Faculty of Veterinary Medicine

Bulevar oslobođenja 18

11000 Belgrade, Serbia

E-mail: snezab@vet.bg.ac.rs

\section{REFERENCES}

1. Anadon A, Abroix Arzo M, Bories G et al., 2005, Opinion of the FEEDAP Panel on the updating of the criteria used in the assessment of bacteria for resistance to antibiotics of human or veterinary importance, EFSA J, 223, 2-11.

2. Axelsson IT, Ahrne SE, Andersson MC, Stahl SR, 1988, Identification and cloning of a plasmidencoded erythromycin resistance determinant from Lactobacillus reuteri, Plasmid, 20, 171-4,

3. Bush K, Jacoby GA, Medeiros AA, 1995, Minireview. A functional classification scheme for âlactamases and its correlation with molecular structure, Antimicrob Agents Chemother, 39, 1211-33.

4. Church DL, Bryant RD, Sim V, and Laishley EJ, 1996, Metronidazole susceptibility and the presence of hydrogenase in pathogenic bacteria, Anaerobe, 2, 147-53.

5. Citak S, Yucel N, Orhan S, 2004, Antibiotic resistance and incidence of Enterococcus species in Turkish white cheese, Int J Dairy Technol, 57, 27-31.

6. Condon S, 1983, Aerobic metabolism of lactic acid bacteria, Ir J Food Sci Technol, 7, 15-25.

7. Danielsen $M, 2002$, Characterization of the tetracycline resistance plasmid pMD5057 from Lactobacillus plantarum 5057 reveals a composite structure, Plasmid, 48, 98-103.

8. Danielsen M, Wind AA, 2003, Susceptibility of Lactobacillus ssp. to antimicrobial agents, Int J Food Microbiol, 82, 1-11.

9. De Fabrizio SV, Parada JL, Ledford RA, 1994, Antibiotic resistance of Lactococcus lactis - an approach of genetic determinants location through a model system, Microbiol Aliment Nutr, 12, 307-15.

10. Delgado S, Florez AB, Mayo B, 2005, Antibiotic susceptibility of Lactobacillus and Bifidobacterium species from the human gastrointestinal tract, Curr Microbiol, 50, 4, 202-7. 
11. Eaton TJ, Gasson MJ, 2001, Molecular screening of Enterococcus virulence determinants and potential for genetic exchange between food and medical isolates, Appl Environ Microbiol, 67, 1628-35.

12. EFSA, 2008, Technical guidance prepared by the Panel on Additives and Products or Substances used in Animal Feed (FEEDAP) on the update of the criteria used in the assessment of bacterial resistance to antibiotics of human and veterinary importance, The EFSA Journal, 1-15.

13. European Food Safety Authority, 2004, EFSA Scientific Colloquium Summary Report. QPS: qualified presumption of safety of microorganisms in food and feed, European Food Safety Authority, Brussels, Belgium.

14. Florez AB, Delgado $S$, Mayo $B, 2005$, Antimicrobial susceptibility of lactic caid bacteria isolated from cheese environment, Can J Microbiol, 51, 51-8.

15. Franz CMAP, Muscholl-Silberhorn AB, Yousif NMK, Vancanneyt M, Swings J, Holzapfel WH, 2001 Incidence of virulence factors and antibiotic resistance among enterococci isolated from food, Appl Environ Microbiol, 67, 4385-9.

16. Giraffa, 2002, Enterococci in foods, FEMS Microbiol Rev, 26, 163-71

17. Gray JW, Stewart D, Pedler SJ, 1991, Species identification and antibiotic susceptibility testing of enterococci isolated from hospitalized patients, Antimicrob Agents Chemother, 35, 1943-5.

18. Halami PM, Chandrashekar A, Nand K, 2000, Lactobacillus farciminis MD, a newer strain with potential for bacteriocin and antibiotic assay, Lett Appl Microbiol, 30, 197-202.

19. Herrero M, Mayo B, Ganzales B, Suarez JE, 1996, Evaluation of technologically important traits in lactic acid bacteria isolated from spontaneous fermentations, $J$ Appl Bacteriol, 81, 565-70.

20. Huys G, D'Haene K, Collard JC, Swings J, 2004, Prevalence and molecular characterization of tetracycline resistance in Enterococcus isolates from food, Appl Environ Microbiol, 70, 1555-62.

21. Kastner S, Parreten V, Bleuler H, Hugenschmidt G, Lacroix C, Meile L, 2006, Antibiotic susceptibility patterns and resistance genes of starter culture and probiotic bacteria used in food, Syst Appl Microbiol, 29, 145-55.

22. Kim KS, Morrison JO, and Bayer AS, 1982, Deficient autolytic enzyme activity in antibiotic-tolerant lactobacilli, Infect Immun, 36, 582-5.

23. Mathur S, Singh R, 2005, Antibiotic resistance in lactic acid bacteria-a review, Int J Food Microbiol, 105, 281-95.

24. Mijačević Z, Bulajić S, 2008, Sensory evaluation and microbiological characterization of autochthonous Sombor cheese, Acta Veterinaria, 58, 5-6, 531-41.

25. Murray PR, Baron EJ, Jorgensen JH, Pfaller MA, Yolken RH, 2003, Manual of Clinical Microbiology, Washington, American Society for Microbiology

26. National Committee for Clinical Laboratory Standards (NCCLS), 2002, Performance Standards for Antimicrobial Susceptibility Testing; twelfth informational supplement, NCCLS document M100-S12 22, 56-8.

27. National Committee for Clinical Laboratory Standards, 1993, Performance Standards for Antimicrobial Disc Susceptibility Test:Tentative Standards 13, 24 NCCLS Documents M2-A5, National Committee for Clinical Laboratory Standards, Vallinova, PA.

28. Normark BH, Normark S, 2002, Evolution and spread of antibiotic resistance, J Intern Med, 252, 91106.

29. Olsson-Liljequist B, Larsson P, Walder M, Miorner H, 1997, Antimicrobial susceptibility testing in Sweden, III. Methodology for susceptibility testing in Sweden, Scand J Infect Dis, 105S, 13-23.

30. Orberg PK, Sandine WE, 1985, Survey of antimicrobial resistance in lactic streptococci, Appl Environ Microbiol, 49, 538-42.

31. Perreten V, Schwarz F, Cresta L, Boeglin M, Dasen G, Teuber M, 1997, Antibiotic resistance spread in food, Nature (London), 389, 801-2.

32. Putman M, van Veen HW, Degener JE, Konings WN, 2001, The lactococcal secondary multidrug transporter $L m r P$ confers resistance to lincosamides, macrolides, streptogramins and tetracyclines, Microbiol, 147, 2873-80.

33. Tammerman R, Pot B, Huys G, Swings J, 2003, Identification and antibiotic susceptibility of bacterial isolates from probiotic products, Int J Food Microbiol, 81, 1-10. 
34. Teuber M, Meile L, and Schwarz F, 1999, Aquired antibiotic resistance in lactic acid bacteria from food, Antonie van Leeuwenhoek, 76, 115-37.

\section{ANTIMIKROBNA OSETLJIVOST BAKTERIJA MLEČNE KISELINE IZOLOVANIH IZ SOMBORSKOG SIRA}

BULAJIĆ SNEŽANA i MIJAČEVIĆ ZORA

\section{SADRŽAJ}

Opsežni literaturni podaci ukazuju da pojedine bakterije mlečne kiseline, čineći dominantnu mikrofloru u fermentisanim proizvodima od mleka, mogu poslužiti kao rezervoar gena rezistencije na antibiotike, potencijalno prenosivih na patogene mikroorganizme. Stoga postoji rastući interes o mogućoj ulozi bakterija mlečne kiseline kao vektora determinanti rezistencije. Ovaj rad izveštava o profilima antibiotske osetljivosti vrsta bakterija mlečne kiseline (rodovi Lactococcus, Lactobacillus i Enterococcus) izolovanih iz različitih linija proizvodnje autohtonog Somborskog sira, tradicionalno proizvedenog bez dodatka starter kulture, a predloženog za dobijanje oznake geografskog porekla. Eksperimentalni rad je izveden u cilju selekcije sojeva koji ne sadrže gene rezistencije na antibiotike, ali su ujedno nosioci poželjnih tehnoloških karakteristika kao što su brza acidifikacija, proteoliza, sposobnost metabolisanja citrata i formiranje aromogenih komponenti. Ujedno, rezultati ovih „screening“ procedura mogu ukazati na tip i stepen antimikrobne rezistencije prisutne među zajednicom bakterija mlečne kiseline Somborskog sira, koji prema geografski određenom području proizvodnje, specifičnom procesu proizvodnje i karakteričnoj aromi i izgledu predstavlja zasebnu ekološku nišu. 